\title{
A new generation ryegrass endophyte - the first results from dairy cows fed AR37
}

\author{
E.R. THOM, C.D. WAUGH, E.M.K. MINNEE and G.C. WAGHORN \\ Dexcel, Private Bag 3221, Hamilton, New Zealand \\ errol.thom@dexcel.co.nz
}

\begin{abstract}
The AR37 endophyte strain in ryegrass produces epoxyjanthitrems but no peramine, lolitrem B or ergovaline, associated with the wild-type (HE) endophyte. An experiment commenced in 2005 to measure dairy cow health and production responses to AR37 in ryegrass. Four herds of 15 cows grazed on each of three endophyte treatments (AR37, AR1, HE and endophytefree (Nil) control) for 12 days in spring 2005 and autumn 2006, and in summer 2006 four groups of 10 cows were fed indoors to accurately assess cow dry matter and alkaloid intakes. Milk yields (kg/cow/day) were similar in spring but in autumn were lower $(\mathrm{P}<0.001)$ for cows fed ryegrass containing HE (11.8) than for those fed AR37 (14.1), AR1 (14.9), and Nil endophyte (14.2) ryegrass. Mild clinical signs of ryegrass staggers were noted in $67 \%$ of cows fed $\mathrm{HE}$ ryegrass in autumn. In summer, ryegrass staggers occurred in all cows fed HE ryegrass and average milk production was lower from these cows $(10.9 \mathrm{~kg} / \mathrm{cow} /$ day $)$ than from those fed AR1 (12.9) and nil (13.5), but not significantly different from cows fed AR37-infected ryegrass $(11.6 \mathrm{~kg} / \mathrm{cow} /$ day). No deleterious effects of AR37 on animal health were observed in any season. This experiment is ongoing and a more definitive evaluation of the AR37 endophyte is anticipated.

Keywords: novel endophytes, milk production, cow health, cow intake, season
\end{abstract}

\section{Introduction}

Advances in ryegrass/endophyte research have provided endophyte strains (e.g. AR1) for New Zealand farmers that protect against insect attack without the animal toxicity associated with the endemic or wild-type (HE) endophyte/ryegrass association.
Commercial release of the AR1 endophyte occurred in 2001 and the demonstration of improved milk production, without ryegrass staggers or heat stress (Bluett et al. 2005) has led to rapid farmer uptake with about $70 \%$ of current perennial ryegrass seed sales containing AR1.

Another novel endophyte, AR37, has been assessed in small plot agronomic comparisons with AR1 and HE over 3-4 years from planting, and at six sites throughout New Zealand (Hume et al. 2004). Total dry matter production of AR37-infected ryegrass exceeded those infected with AR1 by $13 \%$ and those with HE by $9 \%$. AR37 provides protection from a range of insect pests (Popay \& Bonos 2005) and much of its yield advantage has been attributed to this enhanced insect protection.

Work commenced in 2005 to evaluate the effects of AR37 endophyte on cow health, milk production and milk composition. This paper reports results from the first year of study.

\section{Methods}

\section{Experimental site}

The work is being carried out at Dexcel Ltd, Hamilton, New Zealand $\left(37^{\circ} 47^{\prime} \mathrm{S}, 175^{\circ} 19^{\prime} \mathrm{E}, 40 \mathrm{~m}\right.$ a.s.1.) on 15 ha of the Scott Farm. The area is sub-divided into $30,0.5$ ha paddocks for rotational grazing.

\section{Pastures}

A double spraying regime, designed to eliminate the existing pasture and volunteer seedlings, was used before cultivation and drilling on 19 April 2005. 'Commando' perennial ryegrass (Lolium perenne L.) was sown (18 kg/ha), infected with AR37, AR1 or HE endophyte or not infected (Nil), each with 'Tribute'

Table 1 Average milk yield (kg/cow/day), milk solids ( $\mathrm{kg} / \mathrm{cow} /$ day) production, milk composition and feed intake (kg $\mathrm{DM} / \mathrm{cow} /$ day) (summer only) of cows fed ryegrass infected with either AR37, AR1, wild-type (HE) or no endophyte (nil) over 5 days in summer and autumn.

\begin{tabular}{|c|c|c|c|c|c|c|}
\hline & AR37 & AR1 & HE & Nil & SED & Sig. \\
\hline \multicolumn{7}{|c|}{ Summer (indoors) } \\
\hline Milk yield & 11.6 & 12.9 & 10.9 & 13.5 & 0.40 & 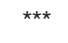 \\
\hline Protein \% & 3.32 & 3.38 & 3.37 & 3.28 & 0.05 & NS \\
\hline Fat $\%$ & 4.99 & 5.00 & 5.04 & 4.88 & 0.13 & NS \\
\hline Milk solids ${ }^{\dagger}$ & 0.95 & 1.07 & 0.91 & 1.09 & 0.03 & 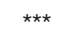 \\
\hline Feed intake & 14.9 & 13.4 & 12.5 & 14.8 & 0.39 & 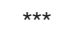 \\
\hline \multicolumn{7}{|c|}{ Autumn (grazing) } \\
\hline Milk yield & 14.1 & 14.9 & 11.8 & 14.2 & 0.32 & *** \\
\hline Protein \% & 3.69 & 3.73 & 3.71 & 3.69 & 0.04 & NS \\
\hline Fat $\%$ & 4.78 & 4.61 & 4.96 & 4.75 & 0.09 & ** \\
\hline Milksolids $^{\dagger}$ & 1.19 & 1.23 & 1.01 & 1.19 & 0.03 & 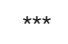 \\
\hline
\end{tabular}

${ }^{\dagger}$ Milk solids $=$ milkfat + milk protein 
white clover (Trifolium repens L.) (3 kg/ha). There were 3 ha (six randomly chosen 0.5 ha paddocks) of each endophyte type. Another 3 ha of the Nil endophyte ryegrass/white clover mixture was also sown to provide endophyte-free grazing for all cows during a covariate period.

"Grow-out" tests before sowing showed the high endophyte status (86-98\%) of the infected seed lines and the low endophyte status $(0 \%)$ of the Nil endophyte seed line. These infection levels were confirmed in April 2006 using a tissue print immunoblot assay (Hahn et al. 2003) of 50 randomly selected tillers per paddock.

Pasture samples from paddocks about to be grazed were cut to ground level daily during each feeding period in spring and autumn. Those collected in the covariate period were bulked again over 6 days to provide a representative sample of what all cows ate while on Nil endophyte ryegrass. A $100 \mathrm{~g}$ sub-sample of pasture was dissected for botanical composition (perennial ryegrass, white clover, other grasses, weeds and dead material of all species) and a $100 \mathrm{~g}$ perennial ryegrass only sub-sample was analysed for lolitrem B and ergovaline using HPLC (Spiering et al. 2002) and epoxy-janthitrems (S. Finch pers. comm.).

Pasture fed indoors in summer was cut to $3-4 \mathrm{~cm}$ of stubble using a tractor-driven 2-drum rotary mower. Herbage samples for botanical and alkaloid analyses were obtained as described above. Another $150 \mathrm{~g}$ sub-sample of pasture was subjected to NIRS analysis (Corson et al. 1999). Botanical dissections also included ryegrass seed head and ryegrass dead material.

\section{Cows}

Sixty mixed-aged spring-calving Holstein-Friesian cows were removed from the main herd and randomly allocated to four groups, balanced for age, calving date, liveweight and milk solids (fat + protein)(MS) production. This was done before spring (24 October to 5 November 2005) and autumn grazing (13 to 25 March 2006) periods, and summer indoor feeding (22 January to 2 February 2006). Treatment herd size in spring and autumn was 15 cows; herds of 10 cows were fed individually in a Calan gate system in summer. Cows had been previously trained to feed in a Calan gate system and had fed there for 5 days before commencing the covariate period. Average cow liveweight at the start of treatment feeding in spring, summer and autumn was 469 $\pm 61,510 \pm 53$ and $495 \pm 42 \mathrm{~kg}$, respectively.

Before each feeding period, all cows were fed Nil endophyte pasture for a 6-day covariate period. Cows were then allocated to their treatment pastures for consecutive 7-day adjustment and 5-day measurement periods. During spring and autumn, pasture was allocated so that cow intake was unrestricted, with an average pre-grazing mass of $3700 \mathrm{~kg} \mathrm{DM} / \mathrm{ha}$. In summer, individual cows were offered $22 \mathrm{~kg} \mathrm{DM} /$ day, which allowed for $15 \%$ refusals. Cows were fed about half their daily ration after morning milking $(8 \mathrm{am})$ and the remainder after the afternoon milking $(3.30 \mathrm{pm})$.

Milk yield and composition (protein, fat and lactose \%) for each cow was measured on 2 days during covariate periods and on every day during measurement periods. Milk yields ( $\mathrm{pm} / \mathrm{am}$ ) were recorded using in-line milk meters and milk composition was determined using the Milkoscan FT120 milk analyser (Foss Electric, Denmark). Unfasted cow liveweight was recorded on consecutive mornings in each covariate period and again in each measurement period, using electronic scales. During summer, water consumption from troughs was measured using in-line water meters and these data were used to estimate cow water intake.

Cows were scored for severity of ryegrass staggers (RGS) once during both the covariate and the measurement periods in spring and autumn. The same procedure was planned for the summer but because all cows in the HE treatment developed RGS by the third day of feeding, scoring was carried out on 2 days during the adjustment and on 3 days during the measurement period. A standard $0-5$ scale $(0=$ no staggers, $5=$ cow unable to stand (adapted from Keogh 1973) was used. In spring and autumn, individual cows were scored after moving them for 5 minutes. Cows were scored indoors in summer in an undisturbed state (lying down or standing).

\section{Statistical analysis}

Treatment effects on milk and MS yield, milk composition and cow intake were analysed using covariate analysis in Genstat (Release 8.2), based on individual cow variation. Pasture data were analysed using ANOVA in Genstat and paddock-to-paddock variation to test for treatment differences.

\section{Results}

\section{Pastures eaten}

Tiller blots carried out 1 year after sowing confirmed the high endophyte status of the endophyte infected pastures with infection rates of 94, 89 and $97 \%$ in AR1, AR37 and HE tillers, respectively. Averaged over the 12 paddocks sown with endophyte-free seed, $5 \%$ of tillers contained endophyte.

During each 5-day measurement period, the botanical composition of the pastures eaten by the cows was similar, regardless of treatment. Predominantly leafy ryegrass $(82 \%$ of DM) was grazed in spring, but by autumn the pasture contained only $42 \%$ ryegrass as white clover increased from $3 \%$ in spring to $38 \%$ of DM. Mature seedhead (average $23 \%$, range 18 to $32 \%$ ) dominated the ryegrass component $(71 \%$ of DM) of the summer pasture. White clover was $22 \%$ of the DM fed in summer. Dead ryegrass accounted for 13,16 and $16 \%$ of DM in spring, summer and autumn, respectively. Summer pastures grew more rapidly than expected with consequent seed head production and more dead matter than would be desirable for high nutritive value (crude protein $15-17 \%$ of DM; neutral detergent fibre, 63-66\% of DM).

The average concentrations of lolitrem B and ergovaline in HE ryegrass over the spring measurement period were low (1.6 and $0.3 \mathrm{mg} / \mathrm{kg}$, respectively) compared with summer (3.8 and $0.6 \mathrm{mg} /$

Table 2 Average change in cow liveweight $(\mathrm{kg})$ over each 12-day treatment feeding period.

\begin{tabular}{lcccccc}
\hline Period $^{\dagger}$ & AR37 & AR1 & HE & Nil & SED & Sig. \\
\hline Spring & 0 & 0 & -10 & 3 & 4.1 & ${ }^{*}$ \\
Summer & 2 & -13 & -24 & -1 & 6.1 & ${ }^{* * *}$ \\
Autumn & -1 & 11 & -8 & 3 & 2.8 & ${ }^{* * *}$ \\
\hline${ }^{\dagger} 60$ cows in spring and autumn, 40 in summer & & & & &
\end{tabular}

${ }^{\dagger} 60$ cows in spring and autumn, 40 in summer 
$\mathrm{kg}$ ) and autumn (3.7 and $0.5 \mathrm{mg} / \mathrm{kg})$. Values were below $0.1 \mathrm{mg} /$ $\mathrm{kg}$ in AR37, AR1 and Nil endophyte ryegrass. The concentrations of epoxy-janthitrems in AR37-infected ryegrass were 3.5, 18.7 and $24.2 \mathrm{mg} / \mathrm{kg}$ in spring, summer and autumn, respectively.

\section{Cows}

Cow milk yields showed no significant treatment differences in spring averaging $16.5 \mathrm{~kg} / \mathrm{cow} /$ day; MS yields averaged 1.22 $\mathrm{kg} / \mathrm{cow} /$ day and protein and fat percentages were 3.21 and 4.19, respectively. In summer (indoors) and autumn (grazing), cows fed HE ryegrass produced the least milk, although AR37 cows had a similar production to HE in summer (Table 1). The protein content of milk produced in summer and autumn was not affected by treatment, but there was a tendency for the fat content of the milk of HE cows to be highest, reaching significance in autumn.

Dry matter intakes of cows fed HE in summer were lower than the other treatments. Intakes were highest in cows fed AR37 and Nil endophyte ryegrass (Table 1). Mean daily water consumption (litres/day), averaged over the 5-day measurement period, was lower for cows on the HE treatment (24.5) than AR37 (36.9), AR1 (40.8) and Nil (34.7). Toxin consumption for HE cows was $48 \mathrm{mg} /$ day of lolitrem B and $8 \mathrm{mg} /$ day of ergovaline, respectively, while AR37 cows consumed $279 \mathrm{mg}$ /day of epoxy-janthitrems over the measurement period.

\section{Liveweight change}

Small but similar liveweight changes were evident in each season for cows fed AR37, AR1 and Nil endophyte ryegrass. In contrast, cows fed HE ryegrass always lost weight and losses were always greater than for cows on other treatments (Table 2).

\section{Ryegrass staggers}

Cows fed AR37, AR1 and nil endophyte ryegrass, showed no clinical signs of RGS in any season, while those fed HE ryegrass showed some head shaking and body swaying in summer and autumn. No other animal health effects were noted.

In summer, RGS was observed in nine out of 10 cows fed HE ryegrass after only 2.5 days of the treatment feeding (beginning of the adjustment period). Average staggers score on a scale of 1 to 5 was 0.9 (range, 0 to 2), increasing to 1.5 (range, 1 to 2 ) by 3.5 days from the start of treatment feeding, when all cows showed signs. This development forced a change to the feeding of $\mathrm{HE}$ cows to avoid termination of this treatment on welfare grounds. The cows were fed Nil endophyte ryegrass in the afternoon of the fourth day of feeding and for the next 2.5 days; HE ryegrass was fed on the afternoon of the last day of the adjustment period (day 7). On the first, third and fourth days of the 5-day measurement period half the diets offered to HE cows contained Nil endophyte ryegrass, with the remainder $\mathrm{HE}$. Average staggers scores for $\mathrm{HE}$ cows on the second, third and fifth days of the measurement period were 0.5 (range, 0 to 1 ), 1.2 (range, 1 to 2 ) and 1.1 (range, 1 to $1.5)$, respectively. Ryegrass from two paddocks was fed over the first 4 days of the adjustment period but alkaloid concentrations were not measured at the time of feeding, however, comparable ryegrass samples collected 2 weeks earlier had high lolitrem B levels (4.9 and $8 \mathrm{mg} / \mathrm{kg} \mathrm{DM}$, respectively).

In autumn, clinical RGS was observed in 10 of the 15 cows that had grazed HE ryegrass for 11 days. The average staggers score for the herd was low (0.6, range 0 to 1.0$)$, however, there was a linear trend $(\mathrm{P}<0.05)$ for cows most affected by RGS (highest staggers score) to have the largest decline in milk yield over the 5-day measurement period.

\section{Discussion}

This paper presents results from the first year of the AR37 endophyte feeding programme for dairy cows and the work is ongoing. The principal observation was that RGS was not recorded in any cows fed AR37-infected ryegrass in any season, although sporadic outbreaks of staggers have occurred in sheep fed AR37 ryegrass (Fletcher 2005). Epoxy-janthitrems are possibly responsible for the animal responses and also insect pest protection (Tapper \& Lane 2004).

As expected, cows eating ryegrass infected with AR1 endophyte did not get staggers, as AR1 does not produce lolitrem B (Bluett et al. 2005). Cows eating HE ryegrass in summer and autumn developed staggers when average lolitrem B levels exceeded 3.5 $\mathrm{mg} / \mathrm{kg}$, as previously reported by Bluett et al. (2005) at the same location. Although only mild staggers occurred in autumn, there was a large loss of milk yield $(2.4 \mathrm{~kg} / \mathrm{cow} /$ day, relative to cows grazing Nil endophyte ryegrass). This was similar to the summer loss when severe staggers was recorded on cut pasture, implying deleterious sub-clinical effects of alkaloid ingestion.

Bluett et al. (2005) did not observe heat stress symptoms in cows eating ryegrass with ergovaline concentrations of 0.2 to $0.7 \mathrm{mg} / \mathrm{kg} \mathrm{DM}$, and this was confirmed in the current work (data not presented).

Concentrations of epoxy-janthitrems in AR37-infected ryegrass followed the seasonal trends of other endophyte-associated animal toxins (lolitrem B and ergovaline) (Thom et al. 1999; Bluett et al. 2005) being lowest in spring and highest in summer/ autumn. Although concentrations of epoxy-janthitrems in AR37infected ryegrass were 5 to 6 times higher than lolitrem B in HE ryegrass, no clinical effects of the AR37 endophyte were noted. This supports the suggestion of Fletcher (2005) that epoxyjanthitrems are less toxic to animals than is lolitrem B.

An interesting feature of milk production was that HE cows produced less than other cows during summer and autumn when RGS was affecting most of the animals. Herbage and water intake data (summer indoor feeding) also suggests cows affected by RGS eat and drink less than cows on other treatments and consequently produced less milk. Liveweights at the beginning and end of short-term feeding also showed HE cows consistently lost more weight than those on the other treatments, probably as a result of lower feed intake.

\section{ACKNOWLEDGEMENTS}

Phil Brink, John Milburn and other Scott Farm staff for management of cows and pastures; Lye Farm staff for cow management during indoor feeding and for cutting and transport of pasture between farms; Mark Bryant, Kate Watkins and Glenise Ferguson provided technical assistance; AgResearch provided the alkaloid and tiller blot analyses and Barbara Dow the statistical analysis; Agricom New Zealand Ltd provided the perennial ryegrass and white clover seed; Dairy InSight provided funding.

\section{REFERENCES}

Bluett, S.J.; Thom, E.R.; Clark, D.A.; Macdonald, K.A.; Minnee, E.M.K. 2005. Effects of perennial ryegrass infected with either AR1 or wild endophyte on dairy production in Waikato. New Zealand Journal of Agricultural Research 48: 197-212.

Corson, D.C.; Waghorn, G.C.; Ulyatt, M.J.; Lee, J. 1999. NIRS: Forage analysis and livestock feeding. Proceedings of the New Zealand Grassland Association 61: 127-132.

Fletcher, L.R. 2005. Managing ryegrass/endophyte toxicosis. 
pp. 229-241. In: Neotyphodium in Cool-Season Grasses. Eds. Roberts, C.A.; West, C.P.; Spiers, D.E. Blackwell Publishing, Iowa.

Hahn, H.; Huth, W.; Schoberlein, W.; Diepenbrock, W. 2003. Detection of the endophytic fungi in Festuca spp. by means of tissue print immunoassay. Plant Breeding 122: 217-222.

Hume, D.E.; Popay, A.J.; Cooper, B.M.; Eerens, J.P.J.; Lyons, T.B.; Pennell, C.G.L.; Tapper, B.A.; Latch, G.C.M.; Baird, D.B. 2004. Effect of a novel endophyte on the productivity of perennial ryegrass (Lolium perenne) in New Zealand. Poster 313. In: Proceedings of $5^{\text {th }}$ International Symposium on Neotyphodium/ Grass Interactions, Fayetteville, Arkansas.

Keogh, R.G. 1973. Induction and prevention of ryegrass staggers in grazing sheep. New Zealand Journal of Experimental Agriculture 1: 55-57.

Popay, A.J.; Bonos, S.A. 2005. Biotic responses in Endophytic Grasses. pp. 163-185. In: Neotyphodium in Cool-Season
Grasses. Eds. Roberts, C.A.; West, C.P.; Spiers, D.E. Blackwell Publishing, Iowa.

Spiering, M.J.; Davies, E.; Tapper, B.A.; Schmid, J.; Lane, G.A. 2002. Simplified extraction of ergovaline and peramine for analysis of tissue distributuion in endophyte-infected grass tillers. Journal of Agriculture and Food Chemistry 50: 58565862.

Tapper, B.A.; Lane, G.A. 2004. Janthitrems found in a Neotyphodium endophyte of perennial ryegrass. Poster 301. In: Proceedings of $5^{\text {th }}$ International Symposium on Neotyphodium/Grass Interactions. Fayetteville, Arkansas.

Thom, E.R.; Clark, D.A.; Waugh, C.D. 1999. Growth, persistence and alkaloid levels of endophyte-infected and endophytefree ryegrass pastures grazed by dairy cows in northern New Zealand. New Zealand Journal of Agricultural Research 42: 241-253. 